\title{
Working Parents \\ and Workplace Flexibility \\ in New Hampshire
}
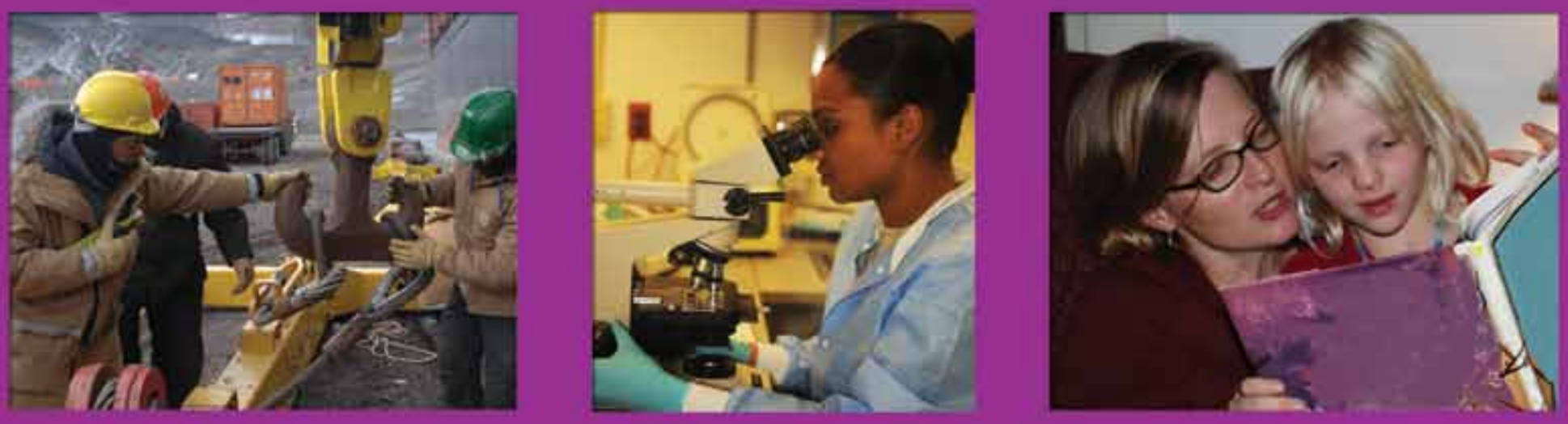

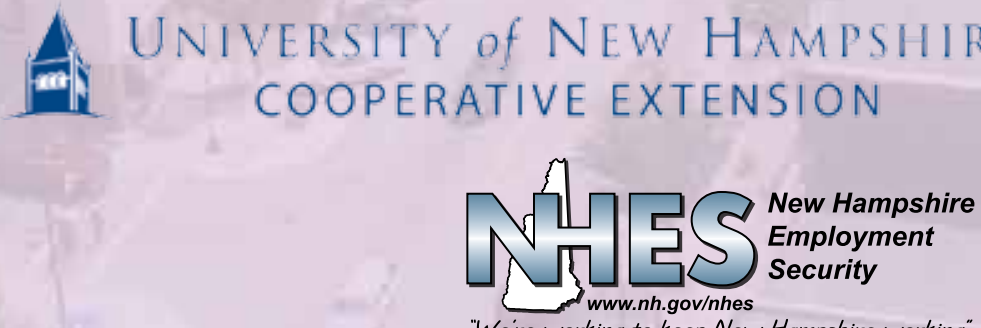

CARSEY

AT THE UNIVERSITY OF NEW HAMPSHIRE 



\section{Working Parents and Workplace Flexibility in New Hampshire}

\section{Kristin Smith and Malcolm Smith}

ome would argue that the widely touted

1 New Hampshire advantage that has attracted and kept many profitable small and large

businesses in New Hampshire is all about not having state taxes. ${ }^{1}$ Others believe it has more to do with the New Hampshire way, the way of life that the Granite State offers those of us who work and live here and who chose to raise our families here. There are some real advantages to living in the Granite State. Our beautiful mountains and lakes and natural spaces, our abundant resources, our sense of community and fairness, our courteous driving habits and our fierce independent spirit all contribute to making New Hampshire a unique place to live.

In the past, our economic environment has also made New Hampshire a great place to live and raise a family. The Annie E. Casey Foundation has consistently ranked New Hampshire, in their national Kids Count program, as one of the best places to raise children. With the state in the throes of an economic crisis and with an aging population, crucial questions have arisen related to what attracts and sustains working families in our state. How can we maintain our economy while ensuring that New Hampshire remains a great place to live and raise healthy, vibrant children who will also want to make their lives here?

At this crucial time in our history, it appears that there needs to be another facet of the New Hampshire way, one that will keep the Granite State a great place to live and work.

\section{"I'm just hanging on to everything} by some tiny threads. If one of those threads breaks, like if my mom is sick and can't look after my son, or my car breaks down, or I get hurt at work, it could all break down and we'd be out on the street." - A father in Berlin, describing the relationship between his work and family life during a focus group.

\section{Key Findings:}

- About half of working parents in New Hampshire stated that their job was "very flexible," while another one-third stated it was "somewhat flexible," and only 8 percent believed their job was "not too flexible."

- Fifty-five percent of working parents in New Hampshire strongly agreed or somewhat agreed that the main reason they are staying in their job is because of the flexibility it offers. Twenty-three percent passed up a promotion for a better job because of uncertainty of being able to negotiate job flexibility.

- Some working parents appear to be making a trade-off between holding a flexible job and having access to paid leave benefits. For example, parents working part-time have more job flexibility but less access to paid leave, while the inverse is true for parents working full-time.

- Working parents' reports of job flexibility increased the longer they have been with an organization. 
New Hampshire's current economic well-being, its future as a leader in New England's commerce, and the viability of its quality of life depend upon its ability to attract, sustain, and adequately reward working families. When working parents are content, firmly planted, and able to manage the complexity of both caring for a family and enjoying a productive work life, the state's economy and the productivity of its businesses also win. ${ }^{2}$ Parents' ability to contribute productively to the economy depends on a partnership between individuals, organizations, communities, and state policy makers to provide simple but important supports for working families. When employers and policy makers come together, they can create powerful momentum. To maintain the New Hampshire way, policy makers and employers need to support ways for workers to find balance between their work, family, and personal needs.

Research has shown that workplace flexibility, particularly in regard to where and how work gets done, benefits employers (in the form of financial benefits and competitive advantage) and employees (in the form of more productivity, lower turnover, and less stress). ${ }^{3}$ In the spring of 2010, the White House launched its first national dialogue on the importance of workplace flexibility in maintaining a healthy U.S. economy. The release of the President's Council of Economic Advisors first report on work-life balance and flexibility signaled a firm national commitment to the issues contained in this brief. New Hampshire, in many ways, is well ahead of this clear national trend, with the ongoing work of the New Hampshire Legislative Task Force on Work and Family, as well as the work of many New Hampshire employers who are leading the call to create more flexible and family friendly work environments.

Our research aims to further examine, understand, and define how New Hampshire's working parents manage the dual challenges of work and family. Through their statements, opinions, and perceptions, we hope to understand the real New Hampshire advantage. This advantage could be endangered by the rapid changes in the nature of employment, changes that strain working families and communities struggling to maintain minimum services to families. By listening to the voices of working parents and enacting sound polices in the statehouse and in business boardrooms based on parents' expressed needs, the New Hampshire way will extend to all working parents in the Granite State.

\section{Developing the Survey of New Hampshire Working Families} The Survey of New Hampshire Working Families was grounded from the beginning in the voices of New Hampshire's working parents. The process of designing questions for the survey began with a series of focus groups at five of New Hampshire's twentythree community-based family resource centers. We questioned diverse groups of working parents, from economically challenged single parents to young mothers to a fathers' support group, about their work and family lives. In total, eighty-eight parents participated in these initial focus groups. ${ }^{4}$

After hearing and recording the voices of these parents, who spoke openly and candidly, we analyzed the content and discovered a series of themes that guided the development of our survey.

\section{Theme 1: Rigidity versus Flexibility in the Workplace}

"The other day, my youngest got sick at school," one working mom told us, "and when I tried to take a minute off the front counter to call the school, my supervisor took my cell phone away."

One of the themes expressed repeatedly and dramatically was the rigidity of some working environments toward issues of tending to family. While some parents told us that their own or their spouse's workplace flexibility allowed them to attend to family matters during work hours, others reported rigid rules that required clocking out, resulted in the loss of pay, or even caused firings when an employee needed to tend to a family member. 
Theme 2: Variability among Supervisors in Supporting Work/Family Fit

"It's like, when we hear the CEO

talk he tells us we're all about flex time," said one young mother in

New Hampshire's North Country, "but when I tried to get time off when my husband got hurt, my supervisor refused to let me make up the hours. He just didn't care."

Some of the working families we listened to described their workplace as being "family friendly" in spirit but told us that their supervisors were often inconsistent or unsympathetic in interpreting those company policies. Participants reported that factors such as gender, longevity, and familiarity with the supervisor influenced interpretation of the company's flexibility policy.

\section{Theme 3: Gender and Family Flexibility}

A frequent theme emerging from both male and female participants was the idea that men have more flexibility to deal with family issues than women in New Hampshire workplaces. One father described it this way:

"Even though I'm a single dad, I didn't tell my boss that when I got custody of my boy. I've seen how they treat the women out at the plant. When they interview women, they kind of assume they are going to miss a lot of work for family stuff, and they make it hard on them from the start. I waited until I had some pull as a reliable guy, then I told 'em I had to be gone for my son and it was no problem."

\section{Theme 4: Fragility and Importance of Family and Community Support}

Many parents in the focus groups described intricate webs of family and community involvement in their working lives. When asked to describe her work day, one mother said she has to drive nearly thirty miles to drop her child off at a relative's house for care, and then drive her husband to work twelve miles in another direction, before returning to her town to drive a school bus all morning.

Working families list a host of community resources among the many supports they rely on to piece together work and family balance, including relatives, neighbors, older siblings, neighborhood child care, family resource centers, home visiting programs, and the work of the Department of Employment Security offices.

\section{Theme 5: Lack of Affordable Resources}

One young mother described her living arrangements to us this way: "It is hard to concentrate on work when you live in a two-room house with your husband, your parents and your two children. We've been waiting on public housing for a year and subsidized day care for another year. Something's got to give."

A litany of lacks was a repeated theme in the focus groups, including a lack of affordable child care, lack of affordable housing, and a lack of other community resources. In some cases, mothers and fathers described living in other nearby states and commuting to their jobs in New Hampshire because the adjoining state offered better child care or housing prices and other support mechanisms.

\section{Theme 6: Uneven Access to Job Flexibility}

An unexpected theme also emerged during the focus groups: Some parents reported their reluctance to seek other employment because of the flexibility of their present job. "I'm not really happy [at my job]," one mother told us, "but if I ever left, I know I couldn't find a place that lets me take care of my kids like this job does."

Some of the participants who worked in family friendly settings described the employer allegiance that family friendly policies generated, an allegiance to the policy but not to the job or the company itself. Working parents may fear that their job is the only one that is flexible and hold that flexibility as key to their ability to manage their work and family responsibilities.

It was clear to these parents that not all companies have the same flexible workplace policies, nor do they have the same workplace cultures. Companies 
that provide flexibility and create a culture that understands the dynamic link between work/life balance and employee allegiance not only keep their employees but also keep them willingly.

\section{Theme 7: Disconnect about Policy Making}

While participants were quick to point out their needs for individual, workplace, community, and state policies and practices that might help them better balance their work and family lives, they weren't clear about who best could help them. When asked whom they might consult about making changes to benefit their work and family lives, the answers we heard most often were "the U.S. president" or "the governor." Participants often

Table 1. Demographic characteristics of working parents, NH 2009

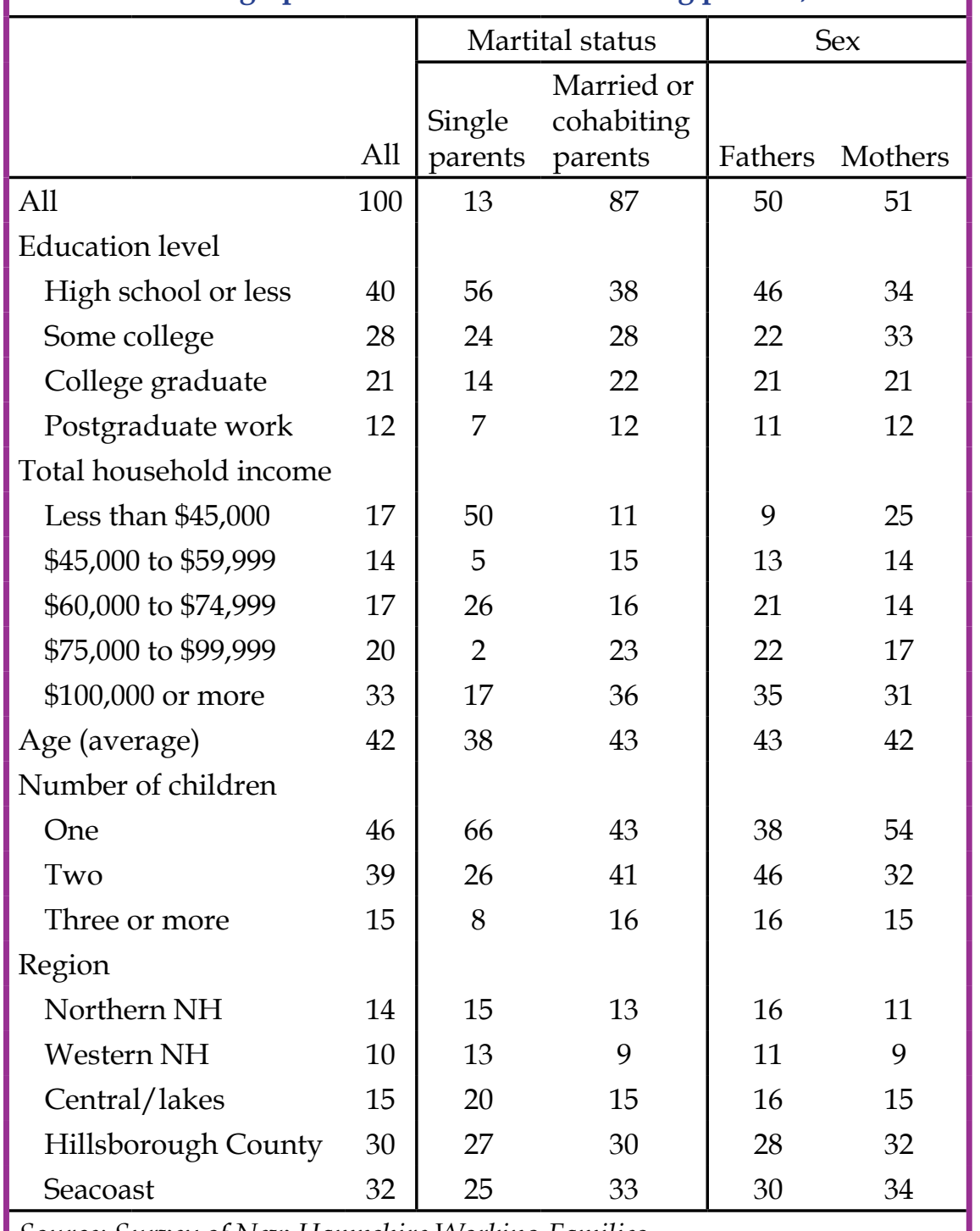

Source: Survey of New Hampshire Working Families minimized the roles of their companies, their bosses, their communities, and state policy makers or local government in making these changes.

These seven themes laid the foundation for the questions we developed for the first Survey of New Hampshire Working Families. While the limitations of sample size and the difficulties accessing low-income working families prevented us from fully addressing all the themes, these voices informed and grounded the structure, definition, and focus of the survey. They are, after all, the voices of New Hampshire's real advantage, the families who live and work within the state's borders.

\section{Who Are New Hampshire's Working Parents?}

The majority of New Hampshire's working parents in our survey were married or cohabiting with a partner (see Table 1). ${ }^{5}$ Among the 13 percent who were single parents, 4 percent were single fathers and 9 percent were single mothers. ${ }^{6}$ Approximately 75 percent were dual-earning couples (data not shown). ${ }^{7}$

The average age of respondents was 42 , and most had one or two children. Single parents were more likely to have only one child living with them, while married parents were equally likely to have one or two children.

In general, married parents had higher education levels than single parents, with one third of married parents having earned a college degree. In contrast, 21 percent of single parents were college graduates. Married parents also had higher family incomes compared with their single counterparts -36 percent of married parents had annual family incomes of $\$ 100,000$ or more, while only half as many (17 percent) of single parents reported incomes at this level. Consistent with most studies of mothers in the United 
States and New Hampshire, the working mothers in our sample, though more highly educated, reported lower total household income than working fathers.

Three-quarters of our participants worked full-time (thirty-five or more hours per week) during the summer of 2009 (see Table 2). Married parents and single parents were equally likely to work full-time, yet married parents worked on average six more hours per week than single parents. A majority of both fathers and mothers worked full-time, yet mothers worked fewer hours than fathers on average. Thirty-five percent of working parents were salaried employees, with fathers having a greater propensity for holding salaried jobs than mothers. Working parents had worked in their jobs for 9 years, on average.

While the majority of working parents worked a regular day shift, a sizable minority had work schedules that varied according to either their employers' needs or their own. Fathers were twice as likely as mothers to have schedules that varied according to their employer's needs. Single parents were less likely to work regular day shifts compared with married parents.

Half of New Hampshire working parents worked in for-profit firms. A greater proportion of single parents than married parents said they worked for a for-profit firm. Fathers were more likely to work for a forprofit firm or to be self-employed than mothers, and mothers were twice as likely to work for notfor-profit organizations. This larger representation of working mothers in not-for-profits is driven by the fact that not-forprofit organizations employ more married mothers than single mothers (data not shown). The government sector employed 15 percent of the working parents in New Hampshire. Roughly 17 percent were self-employed.

The largest proportion of working parents, about four in ten, was employed by large employers ( 250 or more employees). Married parents were more likely to work for large employers than single parents (39 percent and 22 percent, respectively). One in five working parents in New Hampshire worked for employers who have less than ten employees.

\begin{tabular}{|c|c|c|c|c|c|}
\hline & & \multicolumn{2}{|c|}{ Marital status } & \multicolumn{2}{|c|}{ Sex } \\
\hline & All & $\begin{array}{l}\text { Single } \\
\text { parents }\end{array}$ & $\begin{array}{l}\text { Married or } \\
\text { cohabiting } \\
\text { parents }\end{array}$ & Fathers & Mothers \\
\hline All & 100 & 13 & 87 & 50 & 51 \\
\hline \multicolumn{6}{|l|}{ Hours work } \\
\hline Full time & 77 & 72 & 78 & 90 & 65 \\
\hline Hours (average) & 41 & 36 & 42 & 46 & 36 \\
\hline Salaried workers & 35 & 21 & 37 & 45 & 26 \\
\hline Tenure at job (average in years) & 9 & 7 & 9 & 9 & 8 \\
\hline \multicolumn{6}{|l|}{ Work schedule } \\
\hline Regular, daytime & 68 & 58 & 69 & 68 & 68 \\
\hline Regular, non-daytime & 10 & 11 & 10 & 6 & 14 \\
\hline Variable, employer's needs & 9 & 13 & 9 & 14 & 5 \\
\hline Variable, employee's needs & 13 & 18 & 12 & 12 & 14 \\
\hline \multicolumn{6}{|l|}{ Firm size (number of employees) } \\
\hline Less than 10 & 20 & 13 & 21 & 22 & 17 \\
\hline 10 to 25 & 12 & 23 & 10 & 11 & 13 \\
\hline 26 to 99 & 17 & 28 & 16 & 18 & 17 \\
\hline 100 to 249 & 14 & 14 & 14 & 14 & 15 \\
\hline 250 or more & 37 & 22 & 39 & 35 & 39 \\
\hline \multicolumn{6}{|l|}{ Type of employer } \\
\hline Self-employed & 17 & 17 & 17 & 21 & 13 \\
\hline For-profit & 53 & 60 & 52 & 57 & 49 \\
\hline Not-for-profit & 14 & 4 & 15 & 9 & 18 \\
\hline Government & 15 & 15 & 15 & 12 & 17 \\
\hline Other & 2 & 4 & 1 & 1 & 3 \\
\hline \multicolumn{6}{|c|}{ Source: Survey of New Hampshire Working Families } \\
\hline
\end{tabular}




\section{Family and Community Support for Working Families}

"Well, we, my husband and I looked at it really hard. I'd really like to go back to work," one mother of three in Claremont said, "but when we figured out what it would cost for child care, and then when we looked around at the waiting lists for the good places, we just couldn't do it. I love my kids, but I feel like I'm missing out and it will be harder on me to go back when they are in school."

The importance of family and community supports for working families was one of the themes coming out of the focus groups. Affordable, quality child care is vital to helping parents find employment and remain employed. In particular, the reliance among working parents on both relatives and non-relative home care arrangements to care for their children when they work demonstrates that families create patchworks of child care to meet work obligations. Having stable and reliable, as well as affordable child care arrangements is crucial, as it allows parents to get to work on time and stay at work and offers them peace of mind while they are at work.

\section{Child Care Arrangements}

Working parents use a variety of non-parental child care arrangements to care for their children while they work. ${ }^{8}$ Twenty-nine percent of working parents relied on grandparent care while they worked, and single parents relied on grandparent care to a larger extent than married parents ( 50 percent compared with 26 percent) (data not shown). In addition, 18 percent of children under age 14 were cared for by family daycare providers, 21 percent were in organized care facilities, and another 21 percent were in the care of other non-relatives, such as au pairs, babysitters, neighbors, and friends.
When child care arrangements are grouped into two categories - non-relative care arrangements (which includes family daycare providers, organized care facilities, and other non-relatives, such as au pairs, babysitters, neighbors, and friends) and relative care arrangements (which includes grandparents and other relatives but excludes parent care), working parents were more likely to rely on non-relative care arrangements than relative care arrangements (46 percent and 34 percent, respectively) (see Table 3). Since working parents may use more than one child care arrangement during a typical week while they work, the totals in Table 3 do not add up to 100 percent. A larger proportion of single parents relied on non-relative care arrangements while they worked than married parents. Single parents also relied on relatives to care for their children to a large extent, with grandparent care being an important arrangement. Families with very high income levels ( $\$ 100,000$ or more) were more likely to rely on nonrelative care than relative care arrangements, while families earning $\$ 45,000$ or less relied on both non-relative and relative care for their children.

\section{Child Care Costs}

Working parents in New Hampshire who pay for child care, paid an average of $\$ 149$ per week for the care of their youngest child. ${ }^{9}$ Parents paid an average of $\$ 38$ more per week to care for their preschoolers than they paid for their grade school-age children (understandably, as older children spend a large proportion of their day in school).

Child care costs rise as parental education increases. Parents with some post graduate college education paid \$185 per week, while parents with high school degrees or less paid \$148 per week. Similarly, parents with higher incomes paid more for child care. Child care costs also vary depending on where one lives in the state. Working parents living on the Seacoast paid the highest amount per week for child care (\$182 per week), followed by working parents in the north (\$144 per week).

\section{Reliable Child Care}

When it comes to reliability of child care arrangements, working parents in New Hampshire gave their providers high marks. Eighty-nine 
percent of working parents rated their child care arrangements as very reliable. Single mothers were less likely to feel their child care arrangements were very reliable compared with married mothers (68 percent and 90 percent, respectively) (data not shown). Nearly all parents with very high education levels rated their child care arrangements as very reliable, and working parents with high household incomes were similarly pleased with the reliability of their arrangements. This is not surprising because more expensive child care tends to be more reliable.
The "Glue" that Holds it All Together

We asked working parents in New Hampshire to pick one aspect of their work and family life that allows them to maintain a fit between the two - the glue that holds their work and family lives together. ${ }^{10}$ Seven broad categories emerged from the responses: spouse or partner (38 percent); work flexibility (10 percent); family (10 percent); personal strengths (9 percent); children (5 percent); income (3 percent); and religion (3 percent) (data not shown). An additional 14 percent gave other reasons, 8 percent did not know, and 3 percent did not answer the question.

\begin{tabular}{|c|c|c|c|c|}
\hline & \multicolumn{2}{|c|}{ Child care arrangements } & \multirow{2}{*}{$\begin{array}{c}\text { Child } \\
\text { care costs } \\
\text { per week }\end{array}$} & \multirow{2}{*}{$\begin{array}{c}\text { Very } \\
\text { reliable } \\
\text { child care }\end{array}$} \\
\hline & $\begin{array}{l}\text { Relative } \\
\text { care }\end{array}$ & $\begin{array}{c}\text { Non-relative } \\
\text { care }\end{array}$ & & \\
\hline All & 34 & 46 & $\$ 149$ & 89 \\
\hline \multicolumn{5}{|l|}{ Marital status } \\
\hline Single parents & 57 & 69 & $\$ 144$ & 79 \\
\hline Married/cohabiting parents & 32 & 43 & $\$ 150$ & 90 \\
\hline \multicolumn{5}{|l|}{ Age of youngest child } \\
\hline Under 6 years & 34 & 53 & $\$ 163$ & 92 \\
\hline 6 to 14 years & 35 & 42 & $\$ 125$ & 87 \\
\hline \multicolumn{5}{|l|}{ Education level } \\
\hline High school or less & 34 & 47 & $\$ 148$ & 89 \\
\hline Some college & 42 & 46 & $\$ 115$ & 86 \\
\hline College graduate & 27 & 41 & $\$ 160$ & 88 \\
\hline Postgraduate work & 33 & 53 & $\$ 185$ & 97 \\
\hline \multicolumn{5}{|l|}{ Total household income } \\
\hline Less than $\$ 45,000$ & 50 & 54 & $\$ 123$ & 80 \\
\hline$\$ 45,000$ to $\$ 59,999$ & 36 & 42 & $\$ 152$ & 83 \\
\hline$\$ 60,000$ to $\$ 74,999$ & 39 & 54 & $\$ 98$ & 89 \\
\hline$\$ 75,000$ to $\$ 99,999$ & 44 & 46 & $\$ 190$ & 91 \\
\hline$\$ 100,000$ or more & 17 & 41 & $\$ 154$ & 91 \\
\hline \multicolumn{5}{|l|}{ Region } \\
\hline Northern NH & 35 & 49 & $\$ 144$ & 88 \\
\hline Western NH & 42 & 57 & $\$ 94$ & 88 \\
\hline Central/lakes & 33 & 53 & $\$ 141$ & 79 \\
\hline Hillsborough County & 34 & 39 & $\$ 141$ & 93 \\
\hline Seacoast & 32 & 44 & $\$ 182$ & 92 \\
\hline \multicolumn{5}{|c|}{ Source: Survey of New Hampshire Working Families } \\
\hline \multicolumn{5}{|c|}{$\begin{array}{l}\text { Note: Relative care arrangements include grandparents and aunts, uncles, or other } \\
\text { relatives but exclude parents. Non-relative care arrangements include family } \\
\text { daycare providers, organized care facilities, and other non-relatives, such as au } \\
\text { pairs, babysitters, neighbors, and friends. Parents were asked to name all child care } \\
\text { arrangements used to care for their youngest child while they work. Since working } \\
\text { parents may use more than one child care arrangement while they work, the totals do } \\
\text { not add up to } 100 \text { percent. Child care costs rounded to nearest dollar. }\end{array}$} \\
\hline
\end{tabular}

The most common response among married parents was their spouse or partner, followed by work flexibility (see Figures $1 \mathrm{~A}$ and $1 \mathrm{~B}$ ). In contrast, the glue that holds it all together for single parents is much more varied, with one-quarter saying that family is the one thing that keeps it all together, 13 percent saying their own personal strength, and 9 percent saying work flexibility. A larger proportion of single than married parents could not identify the one thing that held their work and family lives together (19 percent and 6 percent, respectively). Similar proportions of single and married parents stated that work flexibility was holding their lives together. Only 4 percent of single parents said their spouse or partner was the one thing holding their work and family lives in balance.

There were significant gender differences in perceptions of supports voiced by women and men in the survey. Although the most common response given by both fathers and mothers was their spouse or partner, a larger proportion of fathers gave this response than mothers (see Figures $2 \mathrm{~A}$ and $2 \mathrm{~B}$ ). Mothers, on the other hand, were twice as likely as fathers to respond that work flexibility held 

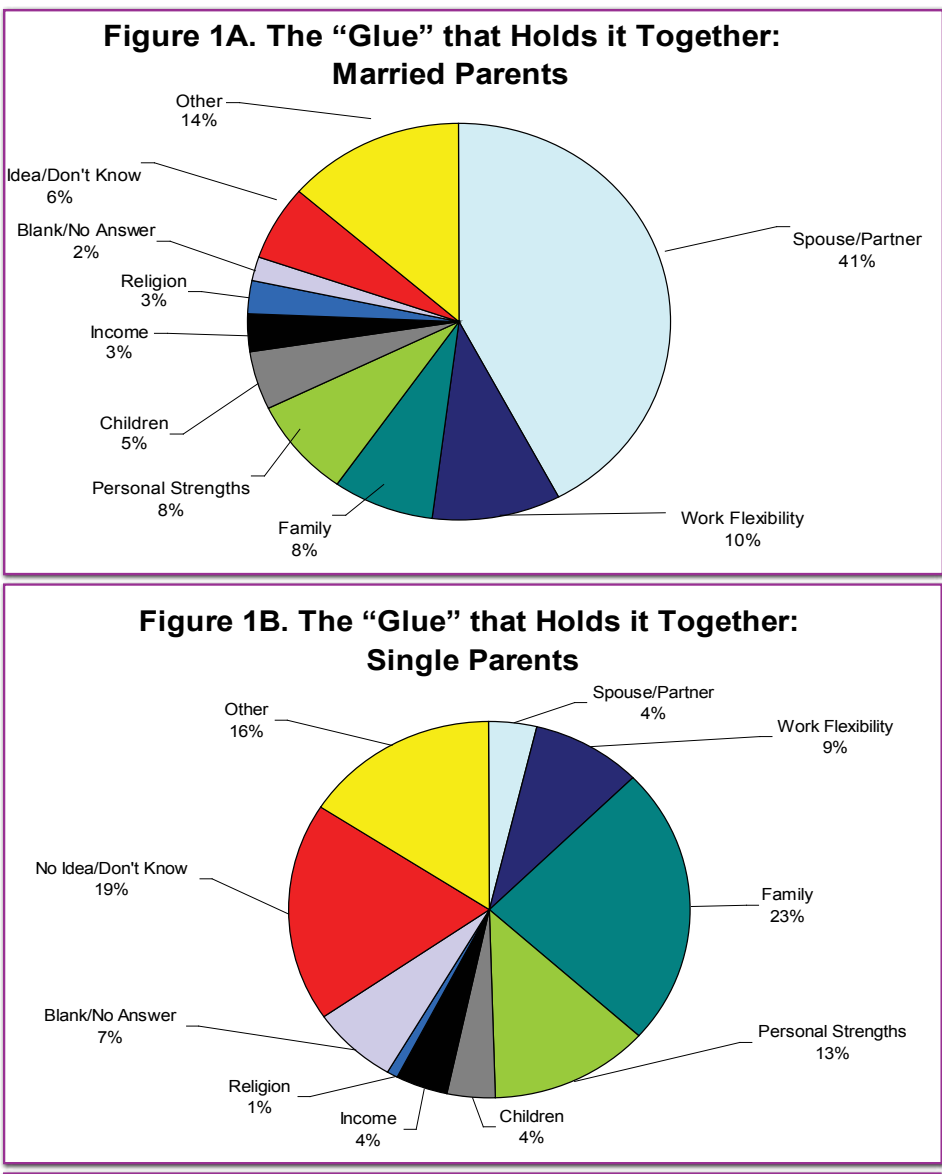

Figure 2A. The "Glue" that Holds it Together: Fathers

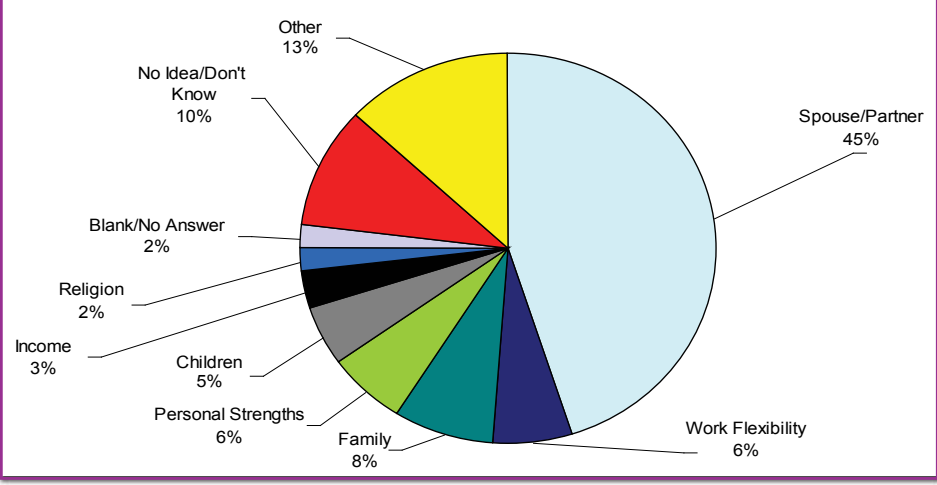

Figure 2B. The "Glue" that Holds it Together:

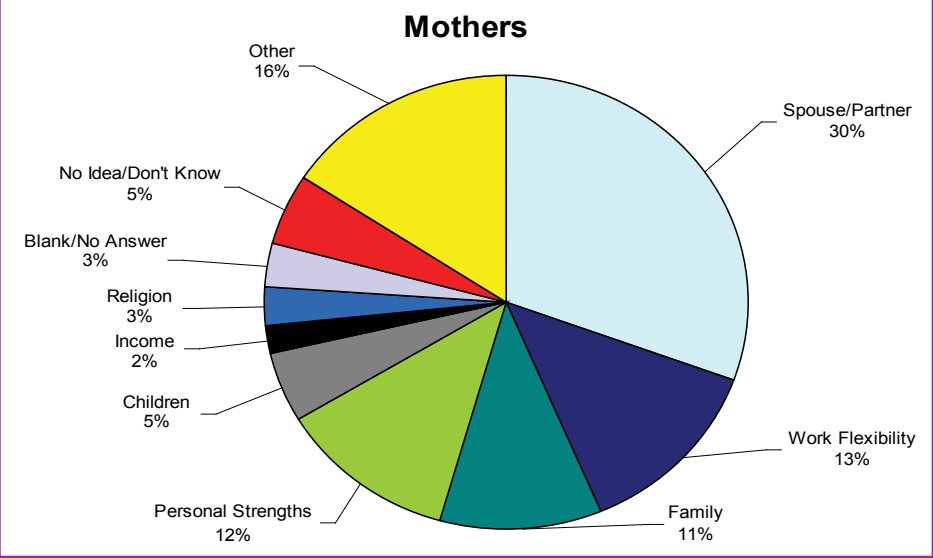

their work and family lives together. Mothers were also more likely than fathers to identify personal strengths or family as the glue. It is not surprising that almost half of fathers responded that their spouse or partner is the one thing holding their work and family lives in balance. Despite the increased time today's fathers spend doing housework, mothers still play the central roles of primary caretaker and family organizer. ${ }^{11}$

These data show that a variety of factors hold the work and family lives of working parents together, suggesting that a one-size-fits-all approach will not meet the needs of all working parents seeking to balance their work and family lives.

\section{Community Resources}

Working families also rely on community resources for support. In total, 11 percent of working parents have participated in a family resource center event supported by UNH Cooperative Extension and 7 percent have attended a UNH Cooperative Extension event related to family issues or parenting (data not shown). While similar proportions of fathers and mothers attended a family resource center event (11 percent), a larger proportion of mothers than fathers attended UNH Cooperative Extension events (9 percent and 5 percent, respectively).

\section{Workplace Support for Working Families}

"It's just plain crazy. We get some real bad storms here in the winter and I'm afraid to drive," said one mother in Gorham. "Then the winter flu season hits. Last year, if it wasn't for my boss letting me take some work home and work late some days to catch up, I would have had to quit. Not everybody has that."

\section{Flexibility in the Workplace}

Life happens. Kids get sick. Family members need to go to the dentist. The furnace breaks down and the service 
person needs to come to the house. Working parents find themselves weighing their family needs and their work obligations, and many times family comes up short. Workers can be reluctant to take time off if the leave is unpaid or if the workplace culture demands setting the needs of work over family. ${ }^{12,13}$ They may also fear that tending to family responsibilities will hurt their chances for promotion. ${ }^{14}$

Yet, job flexibility has been shown to have strong positive benefits for both workers and for employers. Workplace flexibility has been found to reduce stress and improve family relationships, ${ }^{15}$ decrease absenteeism and turnover, ${ }^{16}$ and increase job satisfaction and perceptions of work and family balance. ${ }^{17}$ However, some aspects of job flexibility may have some negative implications for family life, such as flexible work hours and telecommuting, which are associated with longer work hours and the tendency for work to spill over into home life. ${ }^{18}$ Thus, the questions of balance and work/life fit are not solved completely by flexibility alone but may require adjustments in the workplace culture.

For employers, the benefits of offering job flexibility, such as flexible schedules and locations, can outweigh the costs in the form of more productive and focused employees, heightened public approval, greater employee loyalty to the organization, and lower turnover..$^{19}$ Potential challenges to employers include the added responsibility of balancing the needs of clients with those of employees and new complexities in managing and scheduling.

Workplace flexibility and access to paid leave are important work supports for all workers but are particularly salient for working parents. There are many different types of flexible work options that offer a variety of ways to vary when, where, and how work gets completed. Some employers may have formal, on-the-books policies, such as paid vacation time or compressed work schedules, which workers can use to tend to family needs when they arise during regular business hours. Whereas other employers may have more informal policies that help parents, e.g., the ability to change their work schedule every now and then, coming in or leaving early or late, or bringing a child to work during a school closing. Flexibility in its many forms appears to be crucial to many working families in allowing them to navigate between their two worlds. Workers who have some control over their schedules to meet the particular demands over their own lives seem to benefit the most.

For some workers, the best arrangement is having the ability to choose which shift to work. For others it is a company policy that allows them to telecommute or to manage their own schedule. For others it is a flexible leave policy that allows for paid personal time, or paid leave to be used by the employee at the employee's discretion. And for others, it is simply the ability to call home to check on children after school without penalty. The following sections describe New Hampshire working parents' access to paid leave and flexible workplace policies, along with their perceptions of their workplace climate regarding family and work life.

\section{Paid Leave Policies}

The most common paid leave benefit accessible to working parents in the Granite State was paid vacation time (71 percent) (see Table 4). Similar proportions had access to paid sick leave and paid personal time (65 percent and 63 percent, respectively). Far fewer, less than half, had access to paid family leave. ${ }^{20}$ Yet, access to paid leave is unequally distributed among working parents, leaving some in a bind when family emergencies arise.

Across the board, working parents with lower education levels or lower income levels were less likely to have access to paid time off options. For example, 55 percent of working parents with a high school degree or less reported having access to paid sick leave, while 86 percent of those with some postgraduate education could take paid sick leave when they were sick. This same pattern of increasing access to paid leave options as education level increases can be seen for paid vacation, paid family leave, and paid personal time. Fathers were more likely to have access to paid vacation leave than mothers.

Full-time working parents were much more likely to have access to paid time off than their part-time counterparts. For example, 72 percent of full-time working parents had paid sick leave and 81 percent 
had paid vacation days. In contrast, only 37 percent of part-time working parents had access to paid sick leave or to paid vacation days. Single parents, who work on average fewer hours per week than married parents in New Hampshire, have less access to paid sick leave or paid vacation days compared with

\begin{tabular}{|c|c|c|c|c|}
\hline & $\begin{array}{c}\text { Paid } \\
\text { vacation } \\
\text { days } \\
\end{array}$ & $\begin{array}{c}\text { Paid } \\
\text { sick } \\
\text { leave } \\
\end{array}$ & $\begin{array}{c}\text { Paid } \\
\text { personal } \\
\text { time } \\
\end{array}$ & $\begin{array}{c}\text { Paid } \\
\text { parental/ } \\
\text { family } \\
\text { leave }\end{array}$ \\
\hline All & 71 & 65 & 63 & 44 \\
\hline \multicolumn{5}{|l|}{ Sex } \\
\hline Fathers & 75 & 66 & 64 & 47 \\
\hline Mothers & 66 & 63 & 62 & 42 \\
\hline \multicolumn{5}{|l|}{ Marital status } \\
\hline Single parents & 54 & 50 & 62 & 42 \\
\hline Married/cohabiting parents & 73 & 67 & 63 & 45 \\
\hline \multicolumn{5}{|l|}{ Education level } \\
\hline High school or less & 65 & 55 & 55 & 36 \\
\hline Some college & 74 & 62 & 65 & 44 \\
\hline College graduate & 72 & 75 & 69 & 55 \\
\hline Postgraduate work & 81 & 86 & 76 & 56 \\
\hline \multicolumn{5}{|l|}{ Total household income } \\
\hline Less than $\$ 45,000$ & 57 & 47 & 56 & 34 \\
\hline$\$ 45,000$ to $\$ 59,999$ & 57 & 48 & 36 & 32 \\
\hline$\$ 60,000$ to $\$ 74,999$ & 76 & 65 & 72 & 44 \\
\hline$\$ 75,000$ to $\$ 99,999$ & 85 & 82 & 73 & 59 \\
\hline$\$ 100,000$ or more & 74 & 68 & 64 & 47 \\
\hline \multicolumn{5}{|l|}{ Hours work } \\
\hline Part-time & 37 & 37 & 46 & 30 \\
\hline Full-time & 81 & 72 & 68 & 49 \\
\hline \multicolumn{5}{|l|}{ Firm size (number of employees) } \\
\hline Less than 10 & 45 & 36 & 39 & 22 \\
\hline 10 to 25 & 57 & 47 & 59 & 29 \\
\hline 26 to 99 & 67 & 67 & 67 & 45 \\
\hline 100 to 249 & 90 & 74 & 67 & 52 \\
\hline 250 or more & 85 & 82 & 75 & 60 \\
\hline \multicolumn{5}{|l|}{ Type of employer } \\
\hline Self-employed & 36 & 24 & 31 & 21 \\
\hline For-profit & 77 & 68 & 67 & 46 \\
\hline Not-for-profit & 84 & 83 & 80 & 56 \\
\hline Government & 76 & 82 & 73 & 57 \\
\hline \multicolumn{5}{|c|}{ Source: Survey of New Hampshire Working Families } \\
\hline
\end{tabular}

married parents. This lack of paid time off combined with their less-reliable child care arrangements can put them in a bind when family emergencies arise.

Larger firms were more likely to offer formal workplace policies that covered paid time off. As the size of the firm increased, working parents were more likely to report access to paid sick leave, paid vacation days, paid family leave, and paid personal days - workers in firms of 250 or more employees were twice as likely to have access to paid sick leave or paid family leave than workers in firms with fewer than ten employees.

Across the board, the self-employed reported the lowest levels of access to all types of paid leave. Over three-quarters of working parents employed in for-profit companies, not-for-profit organizations, and the government had access to paid vacation days. Access to paid sick leave was similar among working parents employed by not-for-profit organizations and government-sector workers but lower among workers employed at forprofit companies. Workers employed in for-profit companies had lower access to paid family leave than government sector employees and lower access to paid personal time than workers employed in not-for-profit organizations.

\section{Flexible Workplace Policies}

The most common flexible workplace policy available to working parents was the ability to occasionally change the time they start or stop work (64 percent) (see Table 5). Fewer working parents were able to choose the shift they work (50 percent), work a compressed work schedule (43 percent), ${ }^{21}$ request a parttime or reduced work schedule (43 percent), or telecommute or work from home (25 percent).

Working mothers and fathers were equally likely to have the flexibility to 
Table 5. Access to flexible workplace policies among working parents, NH 2009

\begin{tabular}{|c|c|c|c|c|c|}
\hline & $\begin{array}{l}\text { Periodically } \\
\text { change start/ } \\
\text { stop times }\end{array}$ & $\begin{array}{l}\text { Choice } \\
\text { over } \\
\text { shifts }\end{array}$ & $\begin{array}{c}\text { Compressed } \\
\text { workweek }\end{array}$ & $\begin{array}{l}\text { Request } \\
\text { part-time or } \\
\text { reduced work } \\
\text { schedule }\end{array}$ & $\begin{array}{l}\text { Tele-commute/ } \\
\text { work from } \\
\text { home }\end{array}$ \\
\hline All & 64 & 50 & 43 & 43 & 25 \\
\hline \multicolumn{6}{|l|}{ Sex } \\
\hline Fathers & 66 & 51 & 47 & 33 & 29 \\
\hline Mothers & 62 & 49 & 38 & 54 & 21 \\
\hline \multicolumn{6}{|l|}{ Marital status } \\
\hline Single parents & 65 & 47 & 40 & 67 & 26 \\
\hline Married/cohabiting parents & 64 & 50 & 43 & 40 & 25 \\
\hline \multicolumn{6}{|l|}{ Education level } \\
\hline High school or less & 63 & 50 & 48 & 42 & 20 \\
\hline Some college & 65 & 53 & 35 & 43 & 17 \\
\hline College graduate & 67 & 49 & 42 & 47 & 39 \\
\hline Postgraduate work & 61 & 43 & 43 & 40 & 38 \\
\hline \multicolumn{6}{|l|}{ Total household income } \\
\hline Less than $\$ 45,000$ & 62 & 51 & 32 & 60 & 21 \\
\hline$\$ 45,000$ to $\$ 59,999$ & 59 & 36 & 56 & 26 & 13 \\
\hline$\$ 60,000$ to $\$ 74,999$ & 55 & 47 & 37 & 39 & 17 \\
\hline$\$ 75,000$ to $\$ 99,999$ & 69 & 51 & 43 & 35 & 25 \\
\hline$\$ 100,000$ or More & 64 & 46 & 44 & 47 & 32 \\
\hline \multicolumn{6}{|l|}{ Region } \\
\hline Northern NH & 56 & 49 & 41 & 43 & 25 \\
\hline Western NH & 58 & 47 & 36 & 40 & 24 \\
\hline Central/lakes & 59 & 44 & 44 & 45 & 28 \\
\hline Hillsborough County & 66 & 52 & 39 & 44 & 24 \\
\hline Seacoast & 70 & 53 & 49 & 43 & 26 \\
\hline \multicolumn{6}{|l|}{ Hours work } \\
\hline Part-time & 65 & 61 & 51 & 70 & 22 \\
\hline Full-time & 64 & 47 & 40 & 35 & 26 \\
\hline \multicolumn{6}{|l|}{ Firm size (number of employees) } \\
\hline Less than 10 & 74 & 65 & 68 & 36 & 32 \\
\hline 10 to 25 & 61 & 51 & 54 & 53 & 18 \\
\hline 26 to 99 & 69 & 49 & 42 & 52 & 23 \\
\hline 100 to 249 & 57 & 37 & 27 & 44 & 19 \\
\hline 250 or more & 61 & 46 & 34 & 39 & 28 \\
\hline \multicolumn{6}{|l|}{ Type of employer } \\
\hline Self-employed & 82 & 67 & 70 & 46 & 34 \\
\hline For-profit & 66 & 53 & 41 & 48 & 27 \\
\hline Not-for-profit & 56 & 43 & 37 & 43 & 21 \\
\hline Government & 48 & 29 & 29 & 29 & 19 \\
\hline \multicolumn{6}{|c|}{ Source: Survey of New Hampshire Working Families } \\
\hline
\end{tabular}


change the time they start and stop work. Working mothers were more likely to be able to request a parttime or reduced schedule, while working fathers were more likely to be able to work a compressed work schedule or work from home, suggesting that women often had to sacrifice pay in order to have the flexibility they might need in their schedule, whereas men were able to change where or when they worked and still maintain their income.

While paid leave benefits were highly correlated with increasing levels of education or income, access to flexible workplace policies were not. In fact, no set pattern emerged. However, highly educated working parents had less ability to choose the shift they worked but a greater ability to work from home. This makes sense because occupations that require higher degrees often are white-collar jobs, less tied to a specific location.

Part-time working parents were more likely to be able to choose their shift, work a compressed work schedule, or request a part-time or reduced work schedule. With the exception of being able to request fewer work hours and work from home, workers employed in small firms had access to these flexible workplace policies to a larger extent than workers employed in large firms.

A large proportion of the self-employed have access to formal flexible workplace policies, this is not surprising because the self-employed regulate their own schedules. In fact, many seek self-employment to be in control of their work schedules. The selfemployed had the highest levels of access to changing the time they start or stop work, choosing the shift they work, and working a compressed schedule. In contrast, government sector workers had the lowest levels of access to choosing the shift they work and requesting a part-time or reduced work schedule. Workers in for-profit firms were more likely than government sector workers to have the flexibility to change the time they start or stop work or work a compressed work schedule. Workers in not-for-profit organizations were more likely to be able to choose the shift they work than government sector workers. For-profit and not-for-profit workers had similar access to flexible workplace policies.

\section{Figure 3: Trade-off between job flexibility and paid time off}

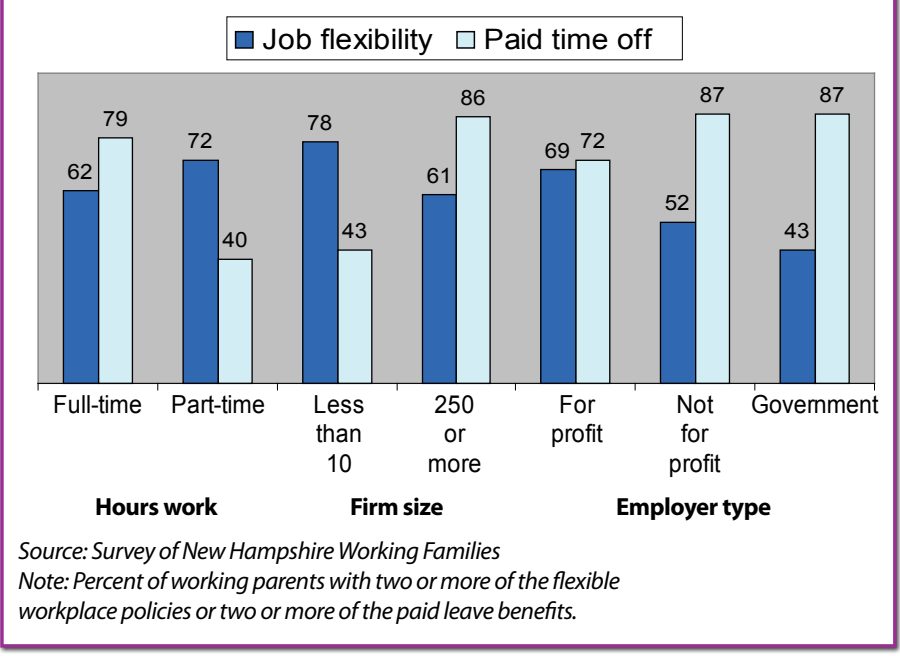

For some working parents, there appears to be a trade-off between holding a flexible job and having access to paid leave benefits. For example, parents working part-time have more job flexibility but less access to paid leave (see Figure 3). In contrast, fulltime workers have more access to paid leave but hold jobs with fewer flexible workplace policies. This makes sense for two reasons: First, benefits such as health insurance and paid sick leave or paid vacation tend to be offered to full-time workers only. Second, many working parents move to part-time work to have more job flexibility.

Similar patterns of trading job flexibility for paid time off and vice versa are seen when comparing firm size and employer type. For example, working parents in small firms enjoy more job flexibility but have less access to paid time off, while the inverse is true as firm size increases. In addition, not-for-profit employees and government workers both have access to paid time off but often lack access to other types of job flexibility. However, workers in for-profit firms do not seem to be making a trade-off; they are just as likely to have paid time off as they are to have access to flexible workplace policies.

\section{Work Climate and Supervisor Support}

The work climate and informal workplace rules (or guidelines) can make a difference in working parents' ability to manage their work and family responsibilities. Supportive workplace cultures and supervisors have a positive influence on work/life balance and help reduce negative workplace spillover 


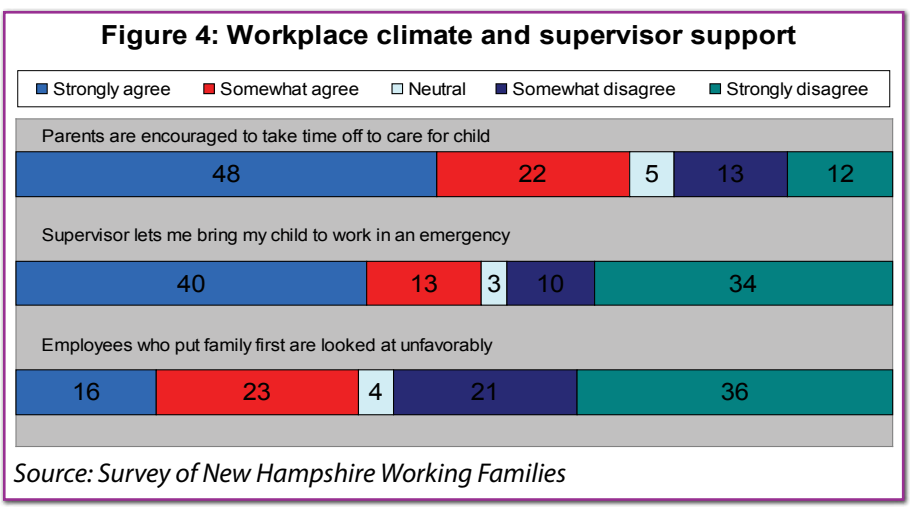

into family life. ${ }^{22}$ Supervisors who allow for workers to bring their children to work when emergencies arise and workplaces that encourage parents to take time off to care for their children offer working parents flexibility as an accepted option when it is necessary. In contrast, if the workplace culture looks unfavorably on employees who need or wish to attend to their families, working parents will have fewer options when emergencies arise.

Forty-eight percent of working parents in the Granite State strongly agreed that in their workplace, parents are encouraged to take time off to care for children, and another 22 percent agreed, although to a lesser extent (see Figure 4). Twelve percent strongly disagreed.

In terms of being able to bring children to work in an emergency, 40 percent of working parents strongly agreed that they would be able to do this. However, 34 percent strongly disagreed, showing great variability in this aspect of workplace cultures across New Hampshire.

Similarly, working parents reported great variability in how their workplace cultures view employees who put their family first. Thirty-six percent of working parents strongly disagreed that employees who put their family first are looked at unfavorably. Yet, 16 percent strongly agreed and another 23 percent agreed somewhat.

\section{Working Parents and Job Flexibility in New Hampshire}

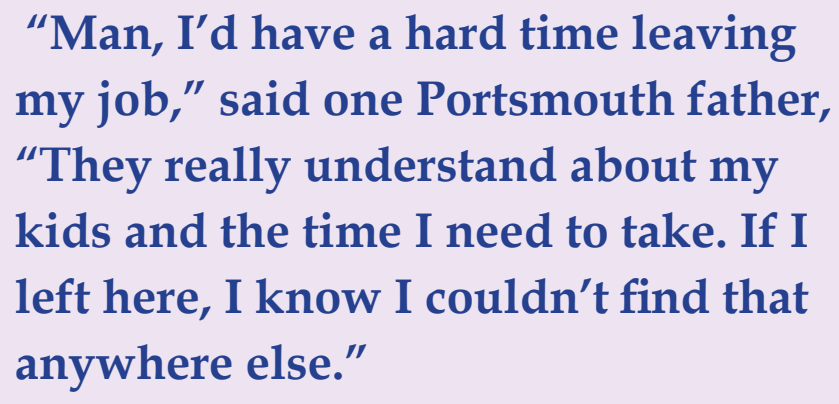
my job," said one Portsmouth father, "They really understand about my kids and the time I need to take. If I left here, I know I couldn't find that anywhere else."

How do working parents rate their jobs in terms of job flexibility in New Hampshire? Just over half stated that their job was "very flexible," while another one-third stated it was "somewhat flexible" (see Table 6). Only 8 percent believed their job was "not too flexible."

Fathers and mothers had similar perceptions about their job flexibility; yet, married parents were more likely than single parents to perceive their job as very flexible. As their education levels increased, working parents were more likely to state their job was very flexible, and the perception of having a very flexible job increased with income. For example, 46 percent of working parents with household incomes of less than $\$ 45,000$ reported their job was very flexible, while 63 percent of those with household incomes of $\$ 100,000$ or more rated their job as very flexible.

One common strategy parents, particularly mothers, use to balance their work and family lives is to work fewer hours. This strategy seems to be delivering the intended payoff of flexibility among New Hampshire's working parents. A larger proportion of part-time working parents stated their job was very flexible (70 percent) compared with their full-time counterparts (52 percent).

Furthermore, workers who are able to vary their schedules according to their own needs by definition will have more job flexibility as they mediate the demands of work and family. Nearly two-thirds of working parents whose work schedules vary according to their own needs felt their jobs were very flexible. In contrast, only about four in ten working parents who work a regular, non-daytime shift or 
whose schedules vary according to their employers' needs stated that their jobs were very flexible.

Working a regular, daytime schedule affords predictability in scheduling for child care and other family needs. About six in ten working parents with regular, daytime work schedules stated their job was very flexible. Workers' reports of job flexibility increased the longer they have been with an organization, suggesting that flexibility may be tied in some sense to longevity with a company.

Perceptions of flexibility varied with the size of the firm or organization and the employer type. Working parents

Table 6. Working parents' perception of job flexibility, NH 2009

\begin{tabular}{|lccc|}
\hline & \multicolumn{3}{c|}{ Flexibility } \\
\cline { 2 - 4 } & Very & Somewhat & Not too \\
\hline Total & 56 & 35 & 8
\end{tabular}

$\begin{array}{llll}\text { Total } & 56 & 35 & 8\end{array}$

Sex

$\begin{array}{llll}\text { Fathers } & 55 & 37 & 9 \\ \text { Mothers } & 58 & 34 & 8\end{array}$

Marital status

Single parents 45 52 3

Married/cohabiting parents 58 33

Education level

High school or less

Some college

$52 \quad 39$

8

College graduate

54

36

10

Postgraduate work

Total household income

Less than $\$ 45,000$

$\$ 45,000$ to $\$ 59,999$

$\$ 60,000$ to $\$ 74,999$

$\$ 75,000$ to $\$ 99,999$

$\$ 100,000$ or more

Hours work

\section{Part-time}

Full-time

Work schedule

\begin{tabular}{lccc} 
Regular, daytime & 60 & 32 & 8 \\
Regular, non-daytime & 42 & 37 & 21 \\
Variable, employer's needs & 41 & 51 & 9 \\
Variable, employee's needs & 64 & 36 & 0 \\
\hline
\end{tabular}

Source: Survey of New Hampshire Working Families

Note: Full-time hours are thirty-five or more hours per week. employed by small firms were more likely to state their job was very flexible compared with those employed by large firms (67 percent and 56 percent, respectively). Two-thirds of working parents employed by not-forprofit firms perceived their job to be very flexible, while one half of working parents employed in the government sector reported high job flexibility.

Working parents who have access to various flexible workplace policies (e.g., the ability to change start/stop work times, compressed work schedules, choice over shift, and ability to work from home) perceive their job as being very flexible to a greater extent than those who do not have access to these policies. For example, 67 percent of working parents who can periodically change the time they start or stop work believe their job is very flexible, while only 38 percent of those who do not have access to this flexible workplace policy had this high perception of job flexibility (see Figure 5). Figure 5 shows a similar pattern for other workplace policies: a higher perception of job flexibility among those with access to other flexible workplace policies.

\section{The Recession and Workplace Flexibility}

We conducted the survey in the summer of 2009, during one of the worst economic recessions in U.S. history. Families have been hit hard with job losses, reduced access to credit, savings losses, mortgage foreclosures, and frozen real estate markets. Given the state of the economy, it is not surprising that more than one-third of working parents in our survey were very or somewhat concerned about losing their jobs (see Table 7).

Working fathers and mothers were similarly concerned about job loss. Working parents with lower levels of household income were more likely to be concerned than their counterparts with household incomes of $\$ 100,000$ or more (data not shown). These figures may indicate a high degree of job stress among some working parents in our state, stress that may grow as current economic turmoil continues in the nation and in New Hampshire.

A majority of working parents stated that their employers' workplace flexibility policies had not changed because of the economy. Nonetheless, a sizable minority -19 percent - of working parents in 


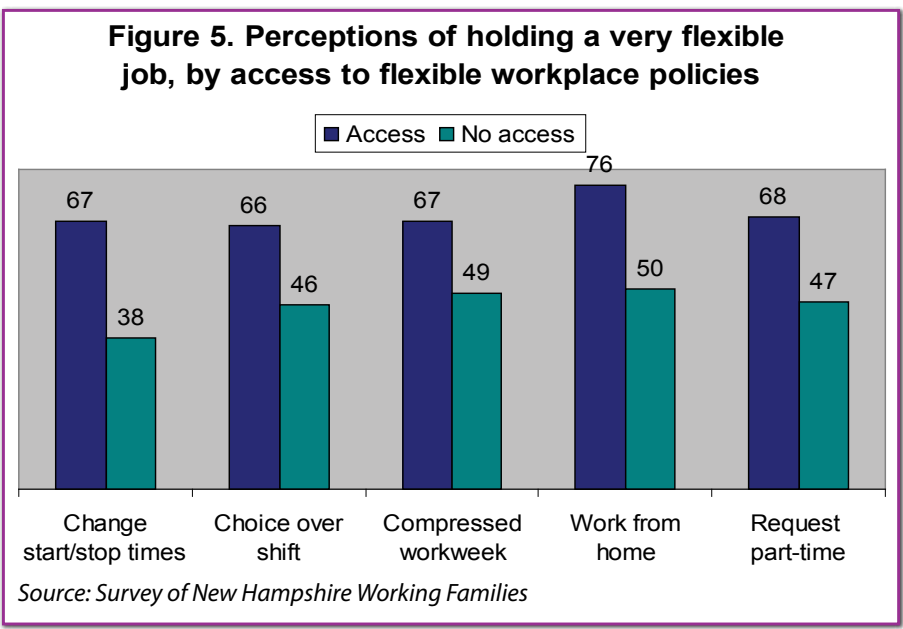

the Granite State believed their workplace flexibility had decreased. Working parents with some college education were more likely to say their workplace flexibility had decreased due to the economy ( 27 percent), compared with those with more than a college diploma (11 percent) (data not shown).

\section{Work-Family Flexibility Trade-off}

In theory, workplace flexibility offers employees the ability to manage family obligations without infringing on work in a way that harms their chances for career advancement and promotions. Yet, because flexible workplace policies are the exception rather than the rule in New Hampshire and across the nation and because more lucrative jobs tend to require long work hours and offer less flexibility, working parents with flexible jobs may be reluctant to move into a more lucrative position, fearing the loss of some of the flexibility. This seems to be the case for working parents in the Granite State.

More than half of working parents in New Hampshire strongly agreed or somewhat agreed that the main reason they are staying in their job is because of the flexibility it offers (see Table 8). Furthermore, almost onequarter of working parents in New Hampshire passed up a promotion to a better job because of uncertainty of being able to negotiate job flexibility.

This is particularly true among working mothers, with 62 percent staying in their job for the flexibility and 28 percent passing up a job promotion in order to keep a job they know to be flexible, suggesting that flexibility, particularly for women, is on par with salary as a leading reason for choosing a job. ${ }^{23}$

Working parents who have flexible jobs value that flexibility and remain in their jobs. Seventy-eight percent of part-time working parents were staying in their job because of the flexibility it offered, and three in ten have passed up a promotion due to uncertainty about flexibility in the new job. In contrast, fewer full-time working parents did so. Working parents employed in small businesses and not-for-profit organizations were staying in their jobs because of the job flexibility as well. These numbers speak well for the relationship that exists between workplace flexibility and allegiance to an employer.

Again, the survey data point to the possibility that some working parents are making tradeoffs, in this case between accepting a job promotion with likely higher pay and maintaining the current level of job flexibility. Until workplace flexibility becomes a workplace standard, akin to the minimum wage, some working parents in New Hampshire will continue to make tradeoffs, underscoring the importance of workplace flexibility for all New Hampshire workers, not just the lucky half. At the same time, employers who provide flexibility will continue to experience allegiance from their employees and find that the length of stay of their employees will increase.

\begin{tabular}{|c|c|c|c|c|c|}
\hline \multicolumn{6}{|c|}{$\begin{array}{l}\text { Table 7. Perceptions of job stability and workplace flexibility } \\
\text { during economic recession, NH } 2009\end{array}$} \\
\hline & \multirow[b]{2}{*}{ Total } & \multicolumn{2}{|c|}{ Marital Status } & \multicolumn{2}{|c|}{ Sex } \\
\hline & & $\begin{array}{l}\text { Single } \\
\text { parents }\end{array}$ & $\begin{array}{c}\text { Married or } \\
\text { cohabiting } \\
\text { parents }\end{array}$ & Fathers & Mothers \\
\hline \multicolumn{6}{|c|}{ Concerned about losing job } \\
\hline Very concerned & 12 & 10 & 13 & 15 & 10 \\
\hline Somewhat concerned & 24 & 8 & 26 & 24 & 23 \\
\hline Not very concerned & 64 & 82 & 62 & 61 & 67 \\
\hline \multicolumn{6}{|c|}{ Change in workplace flexibility } \\
\hline Increased & 8 & 9 & 8 & 8 & 8 \\
\hline Decreased & 19 & 8 & 21 & 23 & 16 \\
\hline No Change & 73 & 83 & 71 & 69 & 76 \\
\hline
\end{tabular}


Table 8. Remaining in current job because of flexibility among working parents, NH 2009

\begin{tabular}{|c|c|c|}
\hline & \multicolumn{2}{|c|}{ Strongly and somewhat agree: } \\
\hline & $\begin{array}{c}\text { Staying in job because } \\
\text { of flexibility }\end{array}$ & $\begin{array}{l}\text { Passed up a promotion } \\
\text { because of flexibility }\end{array}$ \\
\hline All & 55 & 23 \\
\hline \multicolumn{3}{|l|}{ Sex } \\
\hline Fathers & 47 & 19 \\
\hline Mothers & 62 & 28 \\
\hline \multicolumn{3}{|l|}{ Marital status } \\
\hline Single parents & 51 & 21 \\
\hline Married/cohabiting parents & 55 & 24 \\
\hline \multicolumn{3}{|l|}{ Education level } \\
\hline High school or less & 50 & 16 \\
\hline Some college & 54 & 29 \\
\hline College graduate & 63 & 24 \\
\hline Postgraduate work & 56 & 34 \\
\hline \multicolumn{3}{|l|}{ Total household income } \\
\hline Less than $\$ 45,000$ & 58 & 27 \\
\hline$\$ 45,000$ to $\$ 59,999$ & 53 & 21 \\
\hline$\$ 60,000$ to $\$ 74,999$ & 51 & 13 \\
\hline$\$ 75,000$ to $\$ 99,999$ & 63 & 30 \\
\hline$\$ 100,000$ or more & 53 & 24 \\
\hline \multicolumn{3}{|l|}{ Region } \\
\hline Northern NH & 43 & 21 \\
\hline Western NH & 52 & 19 \\
\hline Central/lakes & 56 & 30 \\
\hline Hillsborough County & 53 & 23 \\
\hline Seacoast & 61 & 23 \\
\hline \multicolumn{3}{|l|}{ Hours work } \\
\hline Part-time & 78 & 31 \\
\hline Full-time & 48 & 21 \\
\hline \multicolumn{3}{|l|}{ Firm size (number of employees) } \\
\hline Less than 10 & 70 & 17 \\
\hline 10 to 25 & 53 & 29 \\
\hline 26 to 99 & 46 & 19 \\
\hline 100 to 249 & 48 & 22 \\
\hline 250 or more & 53 & 26 \\
\hline \multicolumn{3}{|l|}{ Type of employer } \\
\hline Self-employed & 71 & 23 \\
\hline For-profit & 50 & 22 \\
\hline Not-for-profit & 63 & 31 \\
\hline Government & 49 & 20 \\
\hline Other & 33 & 24 \\
\hline \multicolumn{3}{|c|}{ Source: Survey of New Hampshire Working Families } \\
\hline
\end{tabular}




\section{Policy Implications}

The findings above represent the voices of a representative sample of 500 New Hampshire working parents. These initial findings of the Survey of New Hampshire Working Families indicate that the New Hampshire way, the advantage provided in the form of job flexibility by our many employers who understand and encourage a way of work that simultaneously promotes job productivity and healthy families, is only available to about half of all New Hampshire working parents. Based on the results emerging from our survey participants, we articulate five clear implications for policy makers and business leaders.

\section{Promote job flexibility for all working parents in New Hampshire.}

The most obvious finding from this data is that about half of New Hampshire's working parents see themselves as working in a very flexible work environment, with another third perceiving their workplace as somewhat flexible. These flexible workplace environments allow working parents not only to care for their children but also to take advantage of the many amenities and opportunities New Hampshire communities offer. These workers stay in place and become loyal to their employers, building productive workplaces and healthy communities.

Yet, the flip side is that about half of working parents in New Hampshire do not perceive their workplace as very flexible. These parents work in environments where the workplace culture is less accommodating to family needs, supervisors monitor phone calls home to check in on family, workers report to work sick or send children to school sick because they lack paid sick leave, and work and family needs collide creating stress and job turnover.

Workplace flexibility appears to be tied to longevity on the job. It is possible that workers who have been with an employer for more time prove that they are trustworthy and then are granted more workplace flexibility. But it is also the case that flexible workplaces retain their workforce as job flexibility reduces stress, decreases absenteeism and turnover, and increases job satisfaction and work and family balance. Employers who offer workplace flexibility gain as well with lower turnover rates, greater employee loyalty, and increased productivity.

Some workers seem to be making tradeoffs between job flexibility and job promotions and higher wages, indicating that working parents hold flexibility as a very important factor in their decision on where to work.

Although we are a very wealthy state, we are also an aging state, and many in the state are focused on creating an atmosphere that will recruit and retain young working families. It is vital to our future and to the viability of our economy that workplace flexibility is offered to all parents, especially parents with young children, for whom flexibility is crucial. Attracting and retaining a younger workforce may be linked to whether younger parents perceive they have access to a way of living that enables them to balance their work and family responsibilities.

Employers who offer workplace flexibility, including flexible work schedules, shift sharing, part-time options, flex-time, and telecommuting earlier in their employees' careers are more likely to create allegiance among those employees and improve those employees' perceptions of their work environment.

\section{Involve working parents in creating individualized workplace and community options.}

While flexibility is an important ingredient in making New Hampshire a great place for working families, we need to make sure that flexibility, or one flexible workplace policy, is not viewed as the sole "magic ingredient" for a healthy workplace environment. Working parents have different needs and "glue" depending on their situation, thus a one-size-fitsall approach will not provide true flexibility for the entire workforce. 
In order to promote job flexibility for all working parents in New Hampshire, employers will need to listen to their employees and craft flexible workplace policies that fit both the employers' and employees' needs. Human resource managers and community leaders will need to involve working parents in creating sound work/life policy development and allow for individualization of those policies.

\section{Develop consistent community support} for New Hampshire working parents. Local and state policy makers and employers need to work to ensure that working parents have access to quality, affordable child care, affordable housing, and healthy family and community environments. When these workplace supports are lacking, working families are challenged in their ability to balance work and family.

In addition, the data indicate that roughly 10 percent of working parents in New Hampshire take advantage of parent education programs offered in the state. Many more parents need stable parent education and support programs such as those offered by the UNH Cooperative Extension and our state's family resource centers. Community, county, and state funding for these programs helps families learn what resources are available to them in their community and learn valuable parenting skills, such as stress management, financial resource management, nutrition, and healthy family relationships.

Preemptive parent education in areas such as child rearing and child development, mental health, healthy lifestyles, and money management offered at the job site during breaks or down time will strengthen employees' personal and professional lives. Work cultures that promote prevention and education can increase allegiance, productivity, and employee loyalty.

For example, the data reveal a high reliance by working parents on family members, grandparents, and partners for balancing their work and family responsibilities. It would bode
New Hampshire employers well to pay attention to these complex, dynamic systems of support that foster work/life balance. Providing employees' partners access to education on relationships, healthy lifestyle promotions, financial and resource management programs, for example, could promote healthy relationships and add to the strength of the "glue" that holds workers' personal and professional lives together.

\section{Develop and promote legislation that} supports family friendly policies in all workplaces.

Access to family friendly working environments should not just be reserved for some working parents in New Hampshire. It is essential to the next generation of New Hampshire workers that their working parents have access to paid sick leave, quality child care, work schedule flexibility, and other workplace options that promote healthy families.

During an economic crisis, it is essential that we not falter in supporting our children and families. Employers and lawmakers must find common ground on matters crucial to raising a healthy, well cared for and well educated new generation of New Hampshire workers.

Policy makers concerned about New Hampshire's aging population should provide incentives and recognition to small and large businesses that provide work cultures attractive to working parents, that offer flexibility, and that understand and support the needs of working parents.

Researchers, human resource professionals, legislators, and managers must consider the quality of family life as essential to the sustainability of the New Hampshire economy and the future of a healthy population.

\section{Consistently support and promote work/life balance as an essential ingredient in workplace culture in New Hampshire.}

In competitive and stressful economic times, recruiting more companies to create stable 
employment and family friendly workplaces for working parents will bolster the economic future of our state. Retaining a competitive advantage is crucial to maintaining the state's status as a leader in the New England economy. Vital to that mission is the perception of New Hampshire as a great place to work and raise a family.

The work of the Legislative Task Force on Work and Family, young-worker initiatives at the state and community levels, and the work of our human resource networks are all essential in promoting work/life initiatives and ideas. Working together at all levels of government and business to promote healthy families, healthy work environments and family friendly communities for all working parents in the Granite State is the New Hampshire way.

\section{Authors}

Kristin Smith, Ph.D. is a family demographer at the Carsey Institute and research assistant professor of sociology at the University of New Hampshire. Contact her at kristin.smith@unh.edu.

Malcolm Smith, Ph.D. is the family life and family policy specialist for the UNH Cooperative Extension and Associate Professor in the Department of Family Studies. He can be contacted at Malcolm.smith@unh. edu or by visiting www.extension.unh.edu.

\section{Acknowledgments}

Data collection was supported by the UNH Cooperative Extension Strategic Initiatives Program. We thank the University of New Hampshire Survey Center for assistance in survey development and data collection. The production of this brief was supported in part by the Carsey Institute at the University of New Hampshire, the Jane's Trust, Family Support New Hampshire (www. fsnh.org), and the Family Support Centers. The layout, formatting, and printing was supported by the New Hampshire Department of Employment Security.

The authors thank Martin Capodice, Special Projects, New Hampshire Department of Employment Security for technical assistance, a keen eye to detail, and overall good humor; Megan Henley, Michelle
Stransky, Sabrina Harris, and Siobhan Whalen, of the University of New Hampshire for research assistance; Representative Mary Stuart Gile, Concord; Benoni Amsden, Plymouth State University; Annie Farnsworth, New Hampshire Commission on the Status of Women; Marybeth Mattingly at the Carsey Institute; and Peg Boyles at UNH Cooperative Extension for their thoughtful comments and suggestions; Scott Koblich and Douglas Hamer at the New Hampshire Department of Employment Security for layout, design, and printing; and the University of New Hampshire Outreach Scholars Academy for support and inspiration.

\section{Data Used}

The data for this brief come from the Survey of New Hampshire Working Families, developed in partnership between the Carsey Institute, the UNH Cooperative Extension, the New Hampshire Department of Employment Security, the New Hampshire Legislative Task Force on Work and Family, and the University of New Hampshire Survey Center and funded by the UNH Cooperative Extension Strategic Initiatives Program. Data were collected during the late spring and early summer of 2009, amid the recession, which began in December 2007. At this time, New Hampshire workers had begun to experience the full effects of the recession and employment figures in the state had dropped, but New Hampshire still fared better than national averages. A representative sample of 500 working parents in New Hampshire were interviewed using random-digit dialing methodologies. The survey has a response rate of 48 percent. Please contact Kristin Smith for more information about the sample, data collection, or to view the survey instrument. Data presented in this brief are weighted and were analyzed by the Carsey Institute staff. Comparisons presented in the text are statistically significant at the 0.05 level. 


\section{Endnotes}

1. A good example of the argument linking low or no taxes to profitable businesses in New Hampshire can be found at www.thenhadvantage.org, one of many groups making this argument in the state.

2. Executive Office of the President, Council of Economic Advisors, "Work-Life Balance and the Economics of Workplace Flexibility," (Washington, D.C. Office of the President of the United States, March, 2010).

3. A Better Balance, "The Business Case for Workplace Flexibility," (New York, NY; March, 2008, Corporate Voices for Working Families, "Business Impacts of Flexibility : An Imperative for Expansion." (Washington, DC 2005): K. A Weeden, "Is there a flexiglass ceiling? Flexible work arrangements and wages in the United States," Social Science Research, 34(2), 454-482 (2005); M. Ezra \& M. Deckman, "Balancing work and family responsibilities: Flextime and childcare in the federal government," Public Administration Review, 56(2) (1996), 174-176; E. Galinsky \& A. Johnson, Reframing the business case for work-life initiatives, (New York: Families and Work Institute, 1998).

4. The five focus group locations and participants included (1) Families First in Portsmouth: a group of parents who were economically challenged, using subsidized child care, or who were in need of public housing; (2) Good Beginnings in Claremont: a group of young working mothers who met regularly; (3) The Upper Room in Derry: a diverse group of mothers, most were stay-at-home mothers with children who participated in a play group while they met for support; (4) The Family Resource Center in Gorham: a group of mothers and fathers who had been courtordered to attend parenting classes; and (5) The HUB in Dover/ Rochester: a group of fathers who meet regularly in a fathers' support group.

5. For the remainder of this brief, we refer to parents who were married or cohabiting as married.

6. We are unable to provide detailed statistics about single fathers due to the small number of single fathers in our sample $(\mathrm{N}=18)$.

7. Comparisons of demographic characteristics of our weighted sample population to working parents in the American Community Survey (ACS) New Hampshire data show that our sample is a good representation of working parents in New Hampshire.

8. We asked respondents to name all the child care arrangements they used to care for their children during the time they worked. Since working parents may use more than one child care arrangement while they work, the totals in Table 3 do not add up to 100 percent.

9. Forty percent of working parents with children under age 14 make child care payments. The remainder either do not use child care arrangements for their children or use non-paid arrangements such as parents, grandparents, or other relatives. These child care cost figures do not take into account the number of hours the child spends in child care.

10. The survey question was the following: "Thinking about all the factors that contribute to and detract from how you manage your work and family life, what is the ONE thing that keeps it all together ... that is, if that person, thing was not there it all would fall apart?" The responses were grouped and coded according to themes.

11. S. Bianchi, J. Robinson, \& M. Milkie, Changing Rhythms of American Family Life, (New York: Russell Sage, 2007).
12. V. Lovell, "No Time to be Sick: Why Everyone Suffers When Workers Don't Have Paid Sick Leave," (Washington, DC: Institute for Women's Policy Research,2004).

13. E. Appelbaum, et al., "Organizations and the intersection of work and family," in S. Ackroyd, R. Batt, \& P.S. Tolbert (Ed.), The Oxford handbook of work and organization, (London: Oxford University Press, 2005) 52-73.

14. D. A. Ralston, "The Benefits of flextime: real or imagined?" Journal of Organizational Behavior, 10(4) (1989), 369-373.

15. Ibid. Ezra and Deckman, 1996.

16. D. R. Dalton \& D. J. Mesch, "The impact of flexible scheduling on employee attendance and turnover" Administrative Science Quarterly, 35(2) (1990), 370-387; Galinksy and Johnson, 1998.

17. E. J. Hill, et al., "Finding an extra day a week: The positive influence of perceived job flexibility on work and family life balance," Family Relations, 50(1) (2001), 49-58; A. L. Saltzstein, Y. Ting, \& G. H. Saltzstein, "Work-family balance and job satisfaction: The impact of family-friendly policies on attitudes of federal government employees," Public Administration Review, 61(4) (2001), 452-467.

18. C. Wharton, "Finding time for the "second shift": The impact of flexible work schedules on women's double days," Gender \& Society, 8(2) (1994), 189-205; and K. Gerson, The Unfinished Revolution: How a New Generation is Reshaping Family, Work, and Gender in America, (London, Oxford University Press, 2010).

19. Ibid. Weeden, 2005; Dalton and Mesch, 1990; P. Kingston, "Illusions and ignorance about the family-responsive workplace," Journal of Family Issues, 11(4) (1990), 438-544.

20. According to Wikipedia, paid family leave refers to leave taken from work for the purpose of recovering from a serious illness, to care for a seriously ill family member or to bond with a newly born or newly adopted child, during which the leave-taker receives some level of financial support from the employer, an insurance policy, or a government program. Other names for paid family leave include "Family Disability Leave", "Family Leave Insurance" and "Paid Parental Leave." See http://en.wikipedia.org/wiki/Paid_family_ leave for more information.

21. According to Businessdictionary.com, a compressed workweek or schedule is where a standard workweek is reduced to fewer than five days and employees make up the full number of hours per-week by working longer hours. Most common options in a compressed workweek are four 10-hour days, three 12-hour days, or a week of five 9-hour days followed by a week of four 9-hour days. See http:/ / www.businessdictionary.com/definition/ compressed-workweek.html for more information.

22. S. F. Mennino, B. A. Rubin, \& A. Brayfield, “Home-to-job and jobto-home spillover: The impact of company policies and workplace culture," The Sociological Quarterly, 46(1) (2005), 107-135.

23. Robert Half International, "The Edge Report," Robert Half International and Careerbuilders.com (2008). See http:/ / www.rhi.com/ for more information. 

The University of New Hampshire Cooperative Extension is an equal opportunity educator and employer. University of New Hampshire, U.S. Department of Agriculture and N.H. counties cooperating. 